Finanse, Rynki Finansowe, Ubezpieczenia nr 5/2017 (89), cz. 2

DOI: $10.18276 /$ frfu. $2017.89 / 2-28$

s. $351-360$

\title{
The signalling effect - changes in the current dividend policy and the future results of the companies - theory and practice*
}

\author{
Andrzej Zyguła**
}

\begin{abstract}
Purpose - The purpose of this article is to present the signalling effect, in particular, to introduce its theoretical foundations and to review major empirical studies on this effect.

Design/methodology/approach - The literature review enabling to identify and discuss the main theoretical and empirical works regarding the signalling effect.

Findings - The conducted study of the literature on the signalling effect leads to a conclusion that although researchers generally agree that dividend payments give some information, there is no consensus on what they really signal.

Originality/value - Dividend theories described in the Polish literature are most often discussed in a collective way. By focusing on only one dividend policy aspect, i.e. the signalling effect, the article offers a more in-depth and comprehensive view of the presented issue.
\end{abstract}

Keywords: dividend, signalling effect

\section{Introduction}

Although the dividend has been known since the sixteenth century, it was only the twentieth century, and, more specifically, the years after World War II, that had the greatest importance for the development of the research on this issue (Lease et al., 2000, p. 5). Decisions on a dividend policy, apart from solutions regarding investments and shaping of an optimal capital structure, are one of the most important areas of financial decisions of companies. A dividend policy, in terms of its impact on the value of a company, has remained one of the most controversial issues in finances for several decades. It might be confirmed by the fact that the debate on a dividend policy was mentioned by Brealey and Myers (2011, p. 872) among the ten most important financial issues, which still have no satisfying theoretical solution.

A long term character and a wide scope of debates have given rise to a vast body of literature, which grows practically day by day. A complete overview of all the topics of this

\footnotetext{
* The publication was financed from resources allocated to the Faculty of Finance of Cracow University of Economics as part of the grant to maintain research capacity.

** dr Andrzej Zyguła, Uniwersytet Ekonomiczny w Krakowie, Katedra Rynków Finansowych, ul. Rakowicka 27, 31-510 Kraków, zygulaa@uek.krakow.pl.
} 
dispute in a single article is thereby not feasible. Therefore, the purpose of this article is to present only one topic i.e. the signalling effect, and, in particular, an implication according to which changes in the current dividend policy and future changes in profits should aim in the same direction. To accomplish this objective, main arguments and explanations underlying the signalling effect have been discussed in the first place. Next, an attempt has been made to order and review the most important empirical studies regarding the mentioned aspect of the effect.

\section{The signalling effect - theoretical foundations}

When Miller and Modigliani (1961) were developing the dividend irrelevance theory, they assumed that both managers (insiders) and investors (outsiders) have identical information about a given company. However, a phenomenon of information asymmetry appears in real conditions of the financial market. Managers, who deal with company affairs on a daily basis, have information about their current situation and prospects, which is not accessible from the outside. This information gap between the knowledge possessed by insiders and outsiders respectively, might cause a situation when the intrinsic value of the company is not known on the market. In such a case, the market price of shares is not always an accurate measure of the value of a company. Managers trying to fill this information gap might face the necessity of sharing their knowledge with investors, e.g. by the means of a dividend. In this way the investors might also know the intrinsic value of the company. Even the above mentioned Miller and Modigliani (1961, p. 430) suggested that prices of shares might react to dividend changes when markets are imperfect. In their opinion, dividend announcement might be perceived as a transmission of classified information on the future income potential of the company. The authors called this type of situation a phenomenon of the informational content of dividends. Currently, it is also referred to as the effect (hypothesis) theory of signalling (Sierpińska, 1999, p. 122; Cwynar, Cwynar, 2007, p. 182; Kowerski, 2011, p. 85; Tuzimek, 2013, p. 181).

According to the signalling theory, investors might make conclusions regarding the future financial results of the company based on signals (information) derived from dividend announcements. However, two conditions must be fulfilled so that this theory could prove true. Firstly, managers must have private information on the prospects of the company, inaccessible from the outside, and must be willing to share it with the market. Secondly, the signal transmitted by managers must be real, i.e. announcements of a dividend growth should be combined with relevant prospects and adequate financial resources so that weak entities with no prospects were not able to imitate such signals and send any false information to the market. Thus, if these two conditions were met, the market should respond positively to the announcement of the dividend growth and react negatively in the opposite situation (Koch, Shenoy, 1999). 
Since managers have more information about the prospects of entities they manage than external investors, they may be able to use announcements of a dividend change as a tool to provide information on the future growth of the company and its profits to the financial market. Meanwhile, external investors might perceive these announcements as a reflection of the managerial evaluation of the current company performance and its prospects. The announcement of a dividend payment increase might, therefore, be interpreted as good news that the company bodes well for the future in terms of the growth and profits, and that is why the prices of its shares "today" should respond positively. Similarly, an announcement of a dividend decrease might be treated as bad news - a signal that the company has weak prospects; the prices of shares "today" might, in that case, react negatively.

For the above reasons, it is not surprising that managers do not want to announce any reductions in a dividend level. Lintner (1956, p. 100) argued already that corporations are generally reluctant to any change in the adopted policy of payment. Managers increase dividends only when they think that company profits will rise permanently and they reduce dividends in the situation where a current level of payments cannot be maintained in the future. This forecast of behaviours is consistent with the so-called dividend smoothing hypothesis. It means that managers will be aiming to smooth a dividend level in the long term and, at the same time, they will not be making any significant current increase in dividend, unless they are be able to keep these increased dividends in the foreseeable future, too. Lipson and others (1998, p. 44) further stated that managers will not even initiate a dividend payment until they do not reach a conclusion that these dividends can be supported by future profits.

It should be noted that the managing board of the company can use a dividend change as a signal to communicate information to the market, but, in some cases, these changes can generate ambiguous signals. The following situation might serve as an example: the company can reduce a dividend payment and use its own resources to finance investments in order to improve its future results. If managers communicate with investors unsuccessfully, the share price may decrease in the short term because the market, not having full information, may mistakenly interpret this event as a signal of deteriorating prospects (Soterennis et al., 1969; Quiry et al., 2005).

Although a phenomenon of the informational content of dividends was already recorded in the capital market in the 1950s and early 1960s, in this initial period it did not possess any theoretical foundations because it was not modelled until the end of 1970s and the beginning of 1980s. Bhattacharya (1979), John and Williams (1985), as well as Miller and Rock (1985), are usually considered to be the creators of a model presentation of the signalling theory and in their theoretical considerations they tried to explain how and why decisions about changes in the level of the dividend payment signal information to the market.

In general, their models are based on different assumptions, but also have something in common. One shared assumption is the presence of the information asymmetry between company managers and shareholders. Managers are considered here as a group possessing 
the best, most complete information on the current situation of the company and its prospects. Secondly, all authors assume that dividend announcements are used as a signalling mechanism because they contain specific information on the company and also because managers have motivation to communicate their private information to the market by these signals in order to close the information gap. Moreover, a common element of the models is a conclusion drawn from them that an announcement of dividend increase is interpreted as a good sign, communicating to the market that a company has good prospects for the future and can afford to increase cash expenditure.

\section{The current changes in a dividend level and the future results of the companies - the practice of the markets}

Researchers (Koch, Shenoy, 1999, p. 17; Allen, Michaely, 2002, p. 66; Al-Malkawi et al., 2010, p. 187; Chen, 2006, p. 27; Seaton, 2006, p. 44; Zenonos, 2003, p. 138) agree that the signalling theory brings important and empirically verifiable implications, focusing on the two of them.

The first implication states that share prices should, immediately after the information announcement, move in the same direction as the announced, unexpected changes of the dividend.

According to the second one, changes in a dividend level should entail identical, in terms of the direction, changes in the level of the future profits. In practice, it deals with the answer to the question whether it is possible to predict the future results of the company based on the changes in its current dividend policy.

The subject literature has devoted a lot of attention to the above mentioned consequences of the signalling effect. In this article, due to its volume limitations, the focus has been put on presenting empirical studies referring only to the second implication. The first implication has been omitted, bearing in mind, however, that it is extremely vital because, if a given dividend announcement does not lead to a specific, predictable reaction of share prices in the short term, then the validity of the conclusions drawn from the signalling hypothesis is doubtful.

Watts (1973) was one of the first scientists who tried to verify a statement that it is possible to forecast future profits in a better way when they are based on the information on the past and current dividend tendencies, rather than on the information on the past and current profits. Watts (1973) tested whether the level of profits in the year $t+1$ can be explained by the current (year $\mathrm{t}$ ) and past (year $t-1$ ) level of dividends or profits using a sample of 310 corporations for the years 1946-1967. The results of all his analyses have shown that the connection between future profits and unexpected current changes in dividends exists, which would confirm the signalling hypothesis. Watts (1973, p. 211), however, taking into consideration the fact that the level of significance of his results was very low, eventually came to a conclusion that the value of information contained in dividends is very small. 
Gonedes (1978) came to similar conclusions regarding the informational content of dividends. The results of the research carried out by Benartzi and others (1997), or DeAngelo and others (1996), also showed the lack of relationship between the ongoing changes in a policy of dividend payment and future profits.

Laub (1976) and Pettit (1976), in response to the above mentioned findings made by Watts (1973), questioned his conclusions in two independent papers published in 1976. Both authors concurred in their deductions that dividends contain information on future profits.

The results obtained by Healy and Palepu (1988) were also partly in line with the signalling theory. Analysing the sample of the companies which initiated the payment of dividends, they found out that profit of those entities increased in the year of initiation and also in the two subsequent years. In the sample of the companies which ceased paying dividends, however, the achieved results were opposite to what the signalling theory predicts. Although the profit of those companies decreased in the year when the cessation of payments was announced, it significantly increased over the next two years.

In the recent publications, which have appeared in the twenty-first century, one can also find a number of studies conducted in the US market, which have attempted to verify the signalling hypothesis. Among that set of tests there are both those that do not support the informational content of the dividends hypothesis and those which results are at least partly consistent with the conclusions of this hypothesis.

For example, Grullon and others (2002), came to the conclusions contrary to the signalling theory. Analysing the sample of the companies which changed their dividend by more than $10 \%$, the authors showed that a dividend increase (or reduction) in the subsequent years was associated with a decrease (or increase) in profitability (ROA) and a decrease (or increase) in the systematic risk. Grullon and others (2005), also demonstrated that dividend changes were negatively correlated with future changes in profitability (ROA). Summing up their results, the authors stated definitively that the changes in the dividend policy do not contain any information about the future profits.

Nissim and Ziv (2001) came to the conclusions opposite to the above presented ones, i.e. to those consistent to some extent with the signalling hypothesis. The results of their research were in line with the findings obtained by Healy and Palepu (1988). Although these authors generally confirm that the changes in dividends and the changes in profits are positively correlated, which supports the signalling hypothesis, simultaneously, they have not found any relationship between the dividend reduction and the future profitability (ROE) of the companies.

However, Howatt and others (2009), fully confirmed the signalling hypothesis in their studies. The research results have shown that an increase/initiation of payment (a reduction/ cessation of payment) of the dividend leads to an increase (or decrease) in the EPS level in the future. Moreover, quite surprisingly, their findings have shown that, contrary to the results of Grullon and others (2002), changes in a dividend level lead to an immediate and future risk increase. 
Chen and Fu (2011), trying to verify, i.a. the signalling hypothesis, obtained, in turn, mixed results. On the one hand, the results of their analyses confirmed regularities relevant to the hypothesis referring to the relationship between a dividend increase and future results measured by the level of profits from a business activity. On the other hand, in the case of a measure of future profits expressed by the EBITDA level (earnings before interest, tax, depreciation and amortization), the results did not prove the hypothesis.

Summing up the above overview of studies, one can form an opinion that the evidence gathered for the American market does not allow to state unambiguously that the changes in the dividend policy carry with them the information about the future results of the companies. A similar conclusion, however, can be reached by following the results of the research conducted on stock markets in other countries.

Research by Chowdhury and others (2010), carried out on the Chinese market, can be mentioned among the works which confirmed the signalling hypothesis. The results of their study showed that an increase (or reduction) in the current level of dividend payments is a positive (or negative) signal about the future profits of companies (the ROE was used as a measure of profit). Similar conclusions were also drawn by Lee (2010), who confirmed the informational content hypothesis, by examining only the cases of dividend increases on the stock market in Singapore (the EPS was used as a measure of profit). In turn, Choi and others (2011), examining the informational content of dividends on the South Korean market, were not able to positively verify the hypothesis, utilising, at first, the entire sample of the companies. However, when they divided the research sample into the companies belonging to chaebols and the ones not belonging to chaebols, they were able to positively verify the hypothesis in the case of the latter (the ROA was used as a measure of profit). In the end, the authors formulated a conclusion that the system of corporate governance in which the companies function, may determine the informational content of dividends. Liljeblom and others (2015), studying the signalling theory in the companies from Denmark, Norway and Sweden, were also not able to positively verify the analysed hypotheses on the basis of the entire sample of companies. However, when they split companies into respective countries, the hypothesis was fully and positively verified for the Swedish companies (the EPS was used as a measure of profit).

Scientists studying the relationships between the current changes in dividend and future profits of the companies in the Iranian, British and Malaysian markets, partly confirmed the signalling hypothesis. In particular, the results of the studies by Lee and others (2012), conducted on the stock market in Malaysia indicated that the changes in dividends (an increase/a decrease) must be of a substantial size (by $50 \%$ or more) to carry a specific signal about the future profits (the EPS was used as a measure of profit), although the scope of this signal was limited to only one year after the changes. In turn, analyses of Ghodrati and Hashemi (2014), conducted for the companies from Iran, showed that an impact of a dividend increase on the future profitability of the companies (the ROE was used as a measure of profit) was positive in the next three years $(+1,+2,+3)$ but statistically significant only in 
the first year. However, in the case of a dividend reduction, the authors did not confirm the occurrence of dependences relevant to the signalling hypothesis. That hypothesis could not also be confirmed by Gwilym and others (2008), in the case of the cessation of payments among the companies from the UK. Yet, the authors found some statistically significant evidence of the positive impact of decisions to resume dividend payments on the future profitability of the companies (the ROE was used as a measure of profit), but only in the first year after that decision. In the case of the two consecutive years, however, profitability decreased.

Similarly to numerous studies which confirm the occurrence of dependencies relevant to the signalling hypothesis on stock markets in many countries to a lesser or greater degree, there are also tests which do not prove it. The lack of the confirmation of the hypothesis can be noted, e.g. on the stock market in Turkey (Kadıoğlu, Öcal, 2016), Thailand (Fairchild et al., 2014), France and Portugal (Vieira, Raposo, 2007) or Switzerland (Stacescu, 2006).

Wrońska (2009), Brycz and Pauka (2013), as well as Pieloch-Babiarz (2015), tried to verify the discussed aspect of the signalling hypothesis on the Polish stock market. In the first case, Wrońska (2009) analysed the relationship between dividends and various measures of the effects of an activity (net profit, operating profit, net cash flow, net operating cash flow), which were achieved by companies both before and after the payment of dividends. However, the results of her study did not confirm the hypothesis, because the final conclusion was a statement that "in the case of the examined companies dividends contain information about past results and can be only used as a signal of this performance". In turn, Brycz and Pauka (2013), referring to the cases of dividend payment initiations, tried to answer the question: "Is it possible to treat information about commencement of dividend payments as actual signals emitted by the management boards of these companies about their expected improved financial condition in the future?". The results of their analyses showed that the companies initiating dividend payments increased their assets and sales revenue in the future, however, as stated by the authors, "forecasting a message of initial dividends regarding future results is no longer strong enough for the investors to base their expectations exclusively on it". The initiation of dividend payments was also a subject of the study by Pieloch-Babiarz (2015), who, unlike the above mentioned authors, proved the signalling hypothesis with her results. In particular, she stated that companies which initiated dividend payments had usually been profitable a few years before $(t-5)$ making the first payment, as well as several years after $(t+4)$, whereas in the first year $(t+1)$ following the year of the initiation, the average profitability of the companies decreased.

\section{Final remarks}

The purpose of this article was to present the signalling effect. To achieve this objective, the paper, in the first place, discussed the basic arguments and explanations constituting theoretical foundations of the presented effect. Subsequently, an attempt was made to overview 
and order empirical studies, which tried to answer the question: "Is it possible to predict future profits of a company on the basis of changes in a current dividend level?". The conducted study of literature leads to a conclusion that, while the researches generally agree that dividend payments give some information, there is no consensus on what they really signal (Frankfurter et al., 2003, p. 99; Benhamouda, 2007, p. 188). The answer to the question if dividends signal the trend of historical profits, or maybe they are a more accurate measure of the current profits or maybe they signal expectations for a future profit, is left open. It seems that the above mentioned lack of consensus confirms that the famous words by Black (1976, p. 5) remain valid despite the passage of time: "The more we look at the picture of dividends, the more it seems to be like a puzzle, which pieces just do not fit together".

\section{References}

Allen, F., Michaely, R. (2002). Payout Policy. The Wharton Financial Institutions Center, Working Paper Series 01-21-B.

Al-Malkawi, H.N., Rafferty, M., Pillai, R. (2010). Dividend Policy: A Review of Theories and Empirical Evidence. International Bulletin of Business Administration, 9, 171-200.

ap Gwilym, O., Clare, A., Seaton, J., Thomas, S. (2008). Dividend Resumptions, Future Profitability and Stock Returns. CAMR Working Papers, Cass Business School City University London. Retrieved from: http://www. cass.city.ac.uk/research-and-faculty/centres/camr/working-papers (12.11.2016).

Benartzi, S., Michaely, R., Thaler, R. (1997). Do changes in dividends signal the future or the past? Journal of Finance, 3 (52), 1007-1034. DOI: 10.1111/j.1540-6261.1997.tb02723.x.

Benhamouda, Z. (2007). UK corporate share repurchases: an empirical analysis of corporate motives and payout policies. Durham theses, Durham University. Retrieved from: http://etheses.dur.ac.uk/2137/ (12.11.2016).

Bhattacharya, S. (1979). Imperfect Information, Dividend Policy, and "The Bird in the Hand" Fallacy. Bell Journal of Economics, 1 (10), 259-270. DOI: 10.2469/dig.v27.n1.3.

Black, F. (1976). The Dividend Puzzle. The Journal of Portfolio Management, 2 (2), 5-8. DOI: 10.3905/ jpm.1976.408558.

Brealey, R.A., Myers, S.C., Allen, F. (2011). Principles of Corporate Finance 10th ed. New York: McGraw-Hill/ Irwin.

Brycz, B., Pauka, M. (2013). Dywidendy inicjalne jako sygnały o przyszłych wynikach na przykładzie spółek z GPW w Warszawie. Zarzadzanie i Finanse, 2 (4), 19-29.

Chen, S.-S., Fu, K.-C. (2011). An Examination of the Free Cash Flow and Information/Signaling Hypotheses Using Unexpected Dividend Changes Inferred from Option and Stock Prices: The Case of Regular Dividend Increases. Review of Pacific Basin Financial Markets and Policies, 3 (14), 563-600. DOI: 10.1142/ S0219091511002329.

Chen, T.-Y. (2006). Payout policy, signalling, and firm value. Durham theses, Durham University. Retrieved from: http://etheses.dur.ac.uk/2660 (12.11.2016).

Choi, Y.M., Ju, H.K., Park, Y.K. (2011). Do dividend changes predict the future profitability of firms. Accounting and Finance, 51, 869-891. DOI: 10.1111/j.1467-629X.2010.00379.x.

Chowdhury, R.H., Maung, M., Zhang, W. (2010). Information Content of Dividends: Evidence from China's Local and Cross-Listed Firms. Northern Finance Association Conference 2010. Retrieved from: http://www.northernfinance.org/2010/NFAPapers2010 (01.06.2015).

Cwynar, A., Cwynar, W. (2007). Kreowanie wartości przez dtugoterminowe decyzje finansowe. Warszawa-Rzeszów: Polska Akademia Rachunkowości.

DeAngelo, H., DeAngelo, L., Skinner, D.J. (1996). Reversal of Fortune: Dividend Signalling and the Disappearance of Sustained Earnings Growth. Journal of Financial Economics, 3 (40), 341-371. DOI: 10.1016/0304-405X(95)00850-E.

Fairchild, R., Guney, Y., Thanatawee, Y. (2014). Corporate dividend policy in Thailand: Theory and evidence. International Review of Financial Analysis, 31, 129-151. DOI: 10.1016/j.irfa.2013.10.006. 
Frankfurter, G.M., Wood Jr., B.G., Wansley, J. (2003). Dividend Policy Theory and Practice. San Diego-London: Academic Press.

Ghodrati, H., Hashemi, A. (2014). A study on relationship between dividend changes with future profitability. Management Science Letters, 4, 1043-1050. DOI: 10.5267/j.ms1.2014.3.004.

Gonedes, N.J. (1978). Corporate Signaling, External Accounting, and Capital Market Equilibrium Evidence on Dividends, Income, and Extraordinary Items. Journal of Accounting Research, 1 (16), 26-79. DOI: 10.2307/2490411.

Grullon, G., Michaely, R., Benartzi, S., Thaler, R.H. (2005). Dividend Changes Do Not Signal Changes in Future Profitability. Journal of Business, 5 (78), 1659-1682. DOI: 10.1086/431438.

Grullon, G., Michaely, R., Swaminathan, B. (2002). Are dividend changes a sign of firm maturity? The Journal of Business, 3 (75), 387-424. DOI: 10.1086/339889.

Healy, P.M., Palepu, K.G. (1988). Earnings Information Conveyed by Dividend Initiations and Omissions. Journal of Financial Economics, 2 (21), 149-176. DOI: 10.1016/0304-405X(88)90059-1.

Howatt, B., Zuber, R.A., Gandar, J.M., Lamb, R.P. (2009). Dividends, earnings volatility and information. Applied Financial Economics, 7 (19), 551-562. DOI: 10.1080/09603100802345397.

John, K., Williams, J. (1985). Dividends, Dilution, and Taxes: A Signalling Equilibrium. The Journal of Finance, 4 (40), 1053-1070. DOI: 10.2307/2328394.

Kadıŏlu, E., Öcal, N. (2016). Dividend Changes and Future Profitability: Evidence from the Turkish Stock Market. International Journal of Economics and Finance, 3 (8), 196-205. DOI: 10.5539/ijef.v8n3p196.

Koch, P.D., Shenoy, C. (1999). The Information Content of Dividend and Capital Structure Policies. Financial Management, 4 (28), 16-35.

Kowerski, M. (2011). Ekonomiczne uwarunkowania decyzji o wypłacie dywidend przez spółki publiczne. KrakówRzeszów-Zamość: Konsorcjum Akademickie.

Laub, P.M. (1976). On the Informational Content of Dividends. Journal of Business, 1 (49), 73-80.

Lease, R.C., John, K., Kalay, A., Loewenstein, U., Sarig, O.H. (2000). Dividend policy. Its impact on firm value. Boston: Harvard Business School Press.

Lee, K.F. (2010). An Empirical Study of Dividend Payout and Future Earnings in Singapore. MPRA Paper, no. 23067. Retrieved from: https://mpra.ub.uni-muenchen.de/23067 (12.11.2016).

Lee, S.-P., Isa, M., Lim, W.-L. (2012). Dvidend changes and future profitability evidence from Malaysia. Asian Academy of Management Journal of Accounting and Finance, 2 (8), 93-110.

Liljeblom, E., Mollah, S., Rotter, P. (2015). Do dividends signal future earnings in the Nordic stock markets? Review of Quantitative Finance and Accounting, 3 (44), 493-511, DOI: 10.1007/s11156-013-0415-3.

Lintner, J. (1956). Distribution of Incomes of Corporations Among Dividends, Retained Earnings, and Taxes. American Economic Review, 2 (46), 97-113.

Lipson, M.L., Maquieira, C.P., Megginson, W. (1998). Dividend Initiations and Earnings Surprises. Financial Management, 3 (27), 36-45.

Miller, M.H., Modigliani, F. (1961). Dividend Policy, Growth, and the Valuation of Shares. Journal of Business, 4 (34), 411-433.

Miller, M.H., Rock, K. (1985). Dividend Policy under Asymmetric Information. Journal of Finance, 4 (40), 10311051. DOI: $10.2307 / 2328393$.

Nissim, D., Ziv, A. (2001). Dividend changes and future profitability. Journal of Finance, 6 (56), 2111-2133. DOI: 10.1111/0022-1082.00400.

Pettit, R.R. (1976). The Impact of Dividend and Earnings Announcements: A Reconciliation. The Journal of Business, 1 (49), 86-96.

Pieloch-Babiarz, A. (2015). Dividend initiation as a signal of subsequent earnings performance - Warsaw trading floor evidence. In: K. Jajuga, W. Ronka-Chmielowiec (eds.), Financial Investments and Insurance - Global Trends and the Polish Market (pp. 301-313). Prace Naukowe Uniwersytetu Ekonomicznego we Wroctawiu, 381. DOI: 10.15611/pn.2015.381.23.

Quiry, P., Dallocchio, M., Le Fur, Y., Salvi, A. (2005). Corporate Finance Theory and Practice. Chichester: John Wiley \& Sons Ltd.

Seaton, J. (2006). Dividends, Payouts and Stock Returns in the United Kingdom. University of Southampton, Phd theses.

Sierpińska, M. (1999). Polityka dywidend w spółkach kapitałowych. Warszawa-Kraków: Wydawnictwo Naukowe PWN.

Soterennis, D., Brigham, E., Evanson, P. (1969). The Dividend Cut "Heard' Round The World": The Case of FPL. Journal of Applied Corporate Finance, 1 (9), 4-16. DOI: 10.1111/j.1745-6622.1996.tb00096.x. 
Stacescu, B. (2006). Dividend Policy in Switzerland. Financial Markets and Portfolio Management, 2 (20), $153-$ 183. DOI:10.1007/s11408-006-0013-7.

Tuzimek, R. (2013). Decyzje finansowe w spótkach giełdowych a wartość akcji. Warszawa: Oficyna Wydawnicza Szkoły Głównej w Warszawie.

Vieira, E., Raposo, C.C. (2007). Signalling with Dividends? New Evidence from Europe. Retrieved from: https:// papers.ssrn.com/sol3/papers.cfm?abstract_id=1004523 (12.11.2016).

Watts, R. (1973). The Information Content of Dividends. Journal of Business, 2 (46), 191-211.

Wrońska, E.M. (2009). Zawartość informacyjna dywidend. Zeszyty Naukowe Uniwersytetu Szczecińskiego, 549, Ekonomiczne Problemy Ustug, 39, 139-145.

Zenonos, M. (2003). The Dividend Policy in Europe: the Cases of the UK, Germany, France and Italy. City University London, Phd theses. Retrieved from: http://openaccess.city.ac.uk/8404 (12.11.2016).

\section{EFEKT SYGNALIZACJI - ZMIANY W BIEŻĄCEJ POLITYCE DYWIDENDY A PRZYSZLE WYNIKI SPÓŁEK - TEORIA I PRAKTYKA}

Streszczenie: $\mathrm{Cel}$ - Celem artykułu jest przedstawienie efektu sygnalizacji a w szczególności przybliżenie jego teoretycznych podstaw oraz dokonanie przeglądu głównych badań empirycznych nad tym efektem.

Metodologia badania - Przegląd literatury umożliwiający zidentyfikowanie i omówienie głównych prac teoretycznych i empirycznych dotyczących efektu sygnalizacji.

Wynik - Przeprowadzone studium literatury, dotyczącej efektu sygnalizacji, prowadzi do wniosku, że wśród naukowców tak jak zasadniczo jest zgoda co do tego, iż wypłaty dywidend niosą z sobą pewne informacje, tak nie ma zgody co do tego co one tak naprawdę sygnalizują.

Oryginalność/wartość - Opisywane w polskiej literaturze teorie dywidendowe omawiane są na ogół w sposób zbiorczy. Artykuł skupiając się tylko na jednym kontekście polityki dywidendowej tj. efekcie sygnalizacji oferuje bardziej dogłębne i kompleksowe spojrzenie na prezentowane zagadnienie.

Słowa kluczowe: dywidenda, efekt sygnalizacji

\section{Citation}

Zyguła, A. (2017). The signalling effect - changes in the current dividend policy and the future results of the companies - theory and practice. Finanse, Rynki Finansowe, Ubezpieczenia, 5 (89/2), 351-360. DOI: 10.18276/ frfu.2017.89/2-28. 